\title{
Frederik Kortlandt
}

\section{HOW OLD IS THE ENGLISH GLOTTAL STOP?}

The discussion of the English glottal stop by Christophersen (1952) and O'Connor (1952) motivated Anatoly Liberman to reconsider the problem of its origin (1972). The main difficulty is that 'neither in RP, nor in the dialects can the glottal stop ever differentiate meaning,' so that 'we must trace whether the glottal stop has not yet achieved relevancy or already lost it' (Liberman 1972:50, 51). In his later work, Liberman definitely opts for the second possibility (1982:237). Here I intend to make clear why I agree with this view in spite of the fact that I do not subscribe to his accentological theory.*

In his survey of the earlier literature, Andrésen comes to the conclusion that 'there is strong evidence in favour of the view that about 1860 the phenomenon of pre-glottalization existed only in a few dialects in Western Scotland' (1968:24). However, it is clear from his examples that this statement refers to the glottal stop which replaces $[\mathrm{p}, \mathrm{t}, \mathrm{k}]$, not to the concomitant glottal closure which accompanies these sounds in more widespread varieties of English. As Andrésen points out himself, it is 'not impossible that pre-glottalization started as a characteristic feature of a certain class dialect, viz. the dialect of the working classes in the big industrial areas' (1968:29). The spread of the replacing glottal stop and its social stigma adequately account for the 'increasing space given by phoneticians from about 1920 onwards to the treatment of the glottal stop' (Andrésen 1968:34), but this does not indicate that the 'reinforcing' glottal closure of [' $p$, 't, ' $k$ ] 'is actually on the increase among educated people' (ibidem). In fact, there is evidence to the contrary.

Collins and Mees have recently advanced our knowledge of the matter by listening 'to a number of pre-1930 audio recordings, together with two recordings of later date, to hunt for what evidence, if any, could be found of glottalisation in the speech of people who had been born in the latter half of the nineteenth century' (1994:75). They were impressed by 'the general pervasiveness of glottalisation in the material we have at our disposal. Far from having to search for odd examples, as we thought might be the case at the outset of our investigation, we have found glottalisation in the speech of all our subjects, even in formal delivery' (1994:78). They conclude that glottalization was well-established in upper-class English speech by the latter half of the nineteenth century and suggest that 'this would imply that glottalisation was even more widespread in the standard language than our observations would indicate' (1994:79). This is in accordance with the view that earlier 
glottalization went unnoticed because it was not distinctive. We may therefore have a look at the comparative evidence.

The comparison of the English glottal stop with the Danish stød is commonplace. There are two varieties of stød in Danish. The standard Danish stød appears in monosyllables which have an acute pitch accent in Swedish and Norwegian. Though its distribution has partly been obscured by analogical levelings, it seems clear that it developed from a falling tone movement. The so-called vestjysk stod of the western dialects is an entirely different phenomenon because it is characteristic of original polysyllables which have a circumflex accent in Swedish and Norwegian. It cannot be connected with the Jylland apocope because it is also found in the northeastern part of vestfynsk dialects, where the apocope did not take place. In his monograph on the vestjysk stød, Ringgaard concludes that 'the $\mathrm{v}$-st $\varnothing \mathrm{d}$ is only found immediately before the plosives $p, t, k$, and that it is found wherever these stand in an original medial position, following a voiced sound in a stressed syllable. The exceptions to this are certain types of loan-words from a later period' (1960:195). He dates the rise of the vestjysk stød to the twelfth century because it is characteristic of 'all then existing medial plosives' (1960:199). The view that the vestjysk st $\varnothing \mathrm{d}$ is a spontaneous innovation of the westernmost dialects of Danish, which Jespersen had in fact already proposed almost half a century earlier (1913:23), can hardly be called an explanation. Moreover, it does not account for the vestjysk stød in the isolated pocket of dialects on the island of Fyn, which suggests that it is a retention rather than an innovation. The hypothesis of a local origin also neglects the parallel development of preaspiration in Icelandic and of the glottal stop in English.

Both the vestjysk stød and the preaspiration receive a natural explanation if we assume that early Proto-Germanic possessed a series of preglottalized voiced stops ' $b$, ' $d$,' 'g (cf. Kortlandt 1985:196, 1988:8). Devoicing yielded a series of late Proto-Germanic sequences ' $p$, ' $t$, ' $k$, the glottal stop of which was lost under various conditions. Weakening of the glottal stop in West Norse yielded preaspiration, while its assimilation to the following plosive gave rise to a series of geminates in East Norse, with the exception of Danish, where the sequences were subject to lenition and the glottal stop was preserved in the vestjysk dialects. Apart from the straightforward explanation of the vestjysk stød and the Icelandic preaspiration, the reconstruction of Proto-Germanic preglottalized stops has the advantage of accounting in a principled way for the existence of several layers of gemination, which can now be viewed as retentions rather than innovations (cf. Kortlandt 1988:7). Firstly, it is possible that the unexplained gemination in Swedish, e.g. in vecka 'week', droppe 'drop', skepp 'ship', reflects a dialect which escaped an early loss of the glottal stop, in contrast with Old Norse vika, dropi, skip, 
Old English wice, dropa, scip. Secondly, $m p, n t, n k$ yielded $p p, t t, k k$ in the larger part of Scandinavia. This development becomes understandable if we assume that the nasal consonant was devoiced by the preaspiration of the following plosive and subsequently lost its nasal feature. Thirdly, ${ }^{*} k$ was geminated before $*^{*} j$ and ${ }^{*} w$, e.g. in Old Norse bekkr 'brook', r $r k k r$ 'dark'. Similarly, ${ }^{*} t$ was geminated before $* j$ in a limited area, e.g. Swedish sätta 'to set'. (West Germanic geminated all consonants except $r$ before $* j$ and is therefore inconclusive.) Fourthly, the stops $p, t, k$ were geminated before $l$ and $r$ in West Germanic, e.g. English apple, bitter, cf. Gothic baitrs. The same development is found sporadically in Scandinavia, which suggests that we are dealing with the loss of an archaic feature rather than with an innovation. Here again, the geminate may have originated from the assimilation of a glottal stop to the following plosive.

Thus, I propose that the English glottal stop directly continues the glottalic feature of the Proto-Germanic preglottalized stops. The gemination in Old High German offan 'open', wazzar 'water', zeihhan 'token' also suggests a complex articulation for the Proto-Germanic voiceless plosives from which they developed. The origin of the gemination is unexplained in the traditional doctrine. If we start from the assumption that the Proto-Germanic plosives were preceded by a glottal stop which is preserved in the vestjysk stød and the English glottalization, the High German sound shift can be explained as a lenition of the plosives to fricatives with a concomitant klusilspring of the preceding glottal stop. Note that the High German sound shift has a perfect analogue in the English dialect of Liverpool, where we find e.g. [kx] in can't, back (Hughes and Trudgill 1987:66), which again remains unexplained in the traditional doctrine.

If the English glottal stop was inherited from Proto-Germanic, we may look for traces in the form of unexpected gemination in medieval sources, to be compared with the gemination in Swedish vecka, droppe, skepp and Old High German offan, wazzar, zeihhan. Such unexplained gemination is indeed found in the Northumbrian Lindisfarne Gospels and Rushworth glosses, e.g. gott, scipp, fott, eatta, brecca (cf. Brunner 1965:189, further Luick 1964:400 and 886). Here $p p$, $t$, $c c$ may represent earlier ['p], ['t], ['k]. Hofmann writes about this gemination: 'Da die Vokaldehnung im Nordenglischen erst für das 12. Jahrhundert angesetzt wird (. . .), müßte es sich um eine andersartige, echte Geminierung einzelner Formen handeln, die die distinktive Funktion der Konsonantenlänge wohl noch nicht aufhob und von der Vokaldehnung unabhängig war' (1989:208). This is a perfect analogue of Swedish vecka, droppe, skepp, which can be explained by the existence of preglottalized stops in the Middle Ages. The hypothesis that the geminates 
represent a purely graphical phenomenon does not explain the short vowel reflexes in later northern English.

It now turns out that the English language offers perhaps the most straightforward evidence for the theory that the unaspirated voiced stops of the Indo-European proto-language were actually glottalized. It follows that the preglottalization which can now be assumed for Old English föt 'foot', nacod 'naked' can be identified with the glottal stop which is attested in Latvian pȩ̧ds 'footstep', nuôgs 'naked'. The antiquity of the English glottal stop is corroborated by glottalization in Danish, Latvian, Lithuanian, Armenian and Sindhi, and supported by indirect evidence from Indo-Iranian, Greek, Latin and Slavic (cf. Kortlandt 1985). This exemplifies once more the importance of re-examining time and again the primary data in linguistic reconstruction.

\section{Cobetstraat 24}

NL-2313 KC Leiden

The Netherlands

*I am indebted to Dirk Boutkan and Rolf Bremmer for references to the literature.

\section{Bibliography}

Andrésen, Bjørn Stålhane. 1968. Pre-Glottalization in English Standard Pronunciation. Oslo: Norwegian Universities Press.

Brunner, Karl. 1965. Altenglische Grammatik. 3. Auflage. Tübingen: Max Niemeyer.

Christophersen, Paul. 1952. 'The Glottal Stop in English.' English Studies 33: 156-63.

Collins, Beverley, and Inger M. Mees. 1994. 'Though'ts on the Glo'ttal Sto'p.' In: Knowing the Words: Liber Amicorum for Robert Druce. Leiden: Academic Press. 68-81.

Hofmann, Dietrich. 1989. 'Die spätgermanische Silbenquantitätsverschiebung und die Doppelschreibung alter kurzer Konsonanten in den altwestfriesischen Quellen.' In his Gesammelte Schriften II: Studien zur friesischen und niederdeutschen Philologie. Hamburg: Helmut Buske. 206-14.

Hughes, Arthur, and Peter Trudgill. 1987. English Accents and Dialects: An Introduction to Social and Regional Varieties of British English. London: Edward Arnold.

Jespersen, Otto. 1913. 'Det danske stød og urnordisk synkope.' Arkiv för nordisk Filologi 29:1-32.

Kortlandt, Frederik. 1985. 'Proto-Indo-European Glottalic Stops: The Comparative Evidence.' Folia Linguistica Historica 6/2:183-201. 
Kortlandt, Frederik. 1988. 'Proto-Germanic Obstruents.' Amsterdamer Beiträge zur älteren Germanistik 27:3-10.

Liberman, Anatoly S. 1972. 'The Glottal Stop in English as Viewed against Its Germanic Background.' Kalbotyra 23/3:45-57.

Liberman, Anatoly S. 1982. Germanic Accentology I: The Scandinavian Languages. Minneapolis: University of Minnesota Press.

Luick, Karl. 1964. Historische Grammatik der englischen Sprache. Stuttgart: Bernhard Tauchnitz.

O'Connor, J.D. 1952. 'RP and the Reinforcing Glottal Stop.' English Studies 33:214-18.

Ringgaard, Kristian. 1960. Vestjysk st $\phi d$. Aarhus: Universitetsforlaget. 